\title{
Substrate and donor specificity of glycosyl transferases
}

\author{
Beat Ernst ${ }^{1 *}$, Reinhold Oehrlein ${ }^{2}$ \\ 1 University of Basel, Institute of Molecular Pharmacy, Totengässlein 3, CH-4057 Basel, Switzerland \\ ${ }^{2}$ Novartis Pharma AG, Department of Transplantation, St. Johann, CH-4002 Basel, Switzerland
}

\begin{abstract}
It has been shown that all selectins recognize the carbohydrate epitopes sialyl Lewis ${ }^{x}$ and sialyl Lewis ${ }^{a}$. For the establishment of the structure-activity relationship, the efficient synthesis of these tetrasaccharides and derivatives is therefore of vital interest. The glycosyl transferase-mediated approach is summarized with emphasis on the use of modified acceptors and modified sugar-nucleotide donors. A survey of the involved enzymes: $\beta(1-3)$ and $\beta(1-4)$ galactosyl transferases, $\alpha(2-3)$ sialyl transferase, FucT III and FucT VI reveals that the enzymatic synthesis is highly efficient for the rapid preparation of sialyl Lewis ${ }^{\mathrm{x}_{-}}$and sialyl Lewis ${ }^{\mathrm{a}}$-derivatives.
\end{abstract}

Keywords: sialyl Lewisx, sialyl Lewisa, enzymatic synthesis, substrate specificity, donor specificity, $\beta(1-3)$ galactosyl transferases, $\beta(1-4)$ galactosyl transferases, $\alpha(2-3)$ sialyl transferase, FucT III, FucT IV

\section{Introduction}

The recent interest in the preparation of natural and modified oligosaccharide structures stems from the numerous demonstrations of their potential as pharmaceuticals [1]. Selected examples are in the area of infectious diseases [2], cancer [3], inflammation [4] or vaccines [5].

This review focusses on the application of enzymatic methods to prepare modified natural carbohydrate epitopes with the potential to inhibit the inflammatory cascade [6].

Numerous diseases and pathological situations are related to excessive influx of leukocytes into tissues. Although this influx normally represents an essential defence mechanism against infection, excessive or inappropriate leukocyte accumulation results in injury to host tissues as observed in ischemia-reperfusion injury, respiratory disease, dermatitis or gastro-intestinal inflammation [7].

Early in the inflammatory response, leukocytes adhere to and roll along endothelial cells on the inner surface of blood vessels. It has been clearly shown that an inducible set of calcium dependent adhesion molecules, the selectins, mediates this initial event [8]. Since leukocyte rolling is a prerequisite for later inflammatory events, blocking select-

To whom correspondence should be addressed. Tel: 011-41-261-7940/41; Fax: 011-41-261-79-07; Email: ERNSTB@ubaclu.unibas.ch ins offers a valuable strategy for preventing the deleterious consequences of excessive leukocyte influx.

It was shown that all selectins recognize the common carbohydrate epitope sialyl Lewis ${ }^{\mathrm{x}}(\mathbf{1})$, albeit with different affinities [9]. In addition, it was firmly established that the selectins also bind sialyl Lewis ${ }^{\text {(2) }}$ [10]. These two tetrasaccharides have, therefore, served as lead structures in our search for selectin antagonists with increased biological activity, simplified structures and improved bioavailability [11].

The advantages of using glycosyl transferases for oligosaccharide synthesis have been well reviewed $[12,13]$ and arise mostly from the mild reaction conditions, the lack of requirement for protection and deprotection steps and the regio- and stereoselectivity of the glycosylation step.

In order to take advantage of these biocatalysts for the synthesis of sialyl Lewis ${ }^{\mathrm{x}}$, sialyl Lewis ${ }^{\mathrm{a}}$ and derivatives thereof, two prerequisites have to be fulfilled: the glycosyl transferases and the sugar nucleotides (nucleotide monoand diphosphate sugars) have to be available on a preparative scale.

\section{Glycosyl transferases and sugar nucleotides}

The Leloir-transferases [14] are key enzymes in the anabolic glycosylation pathway. They transfer a monosaccharide moiety from nucleotide-activated donor sugars regio- 


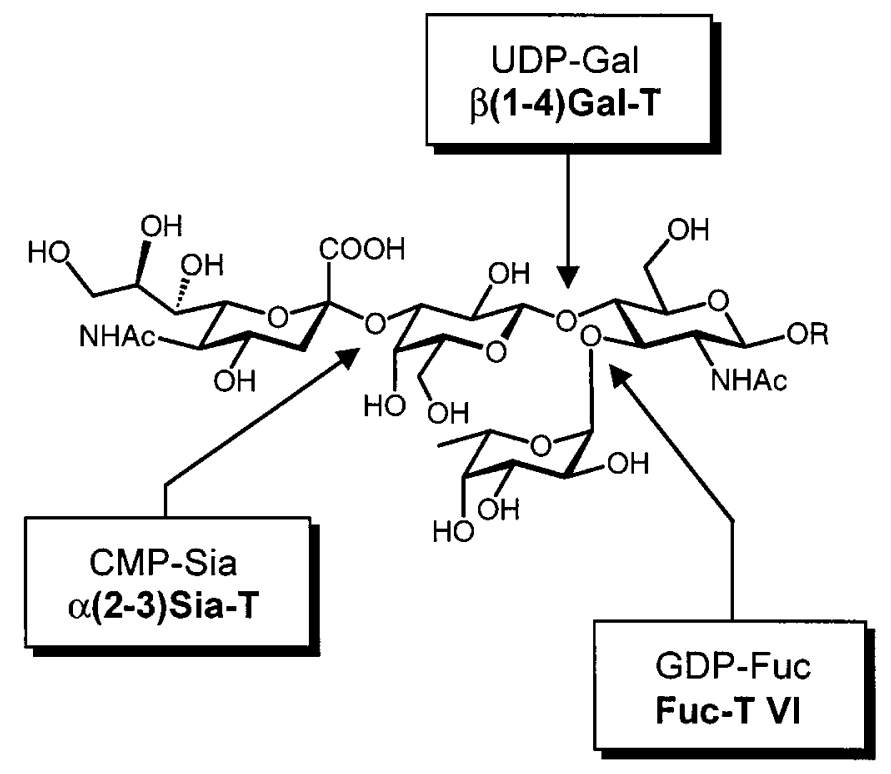

sialyl Lewis ${ }^{x}(1)$

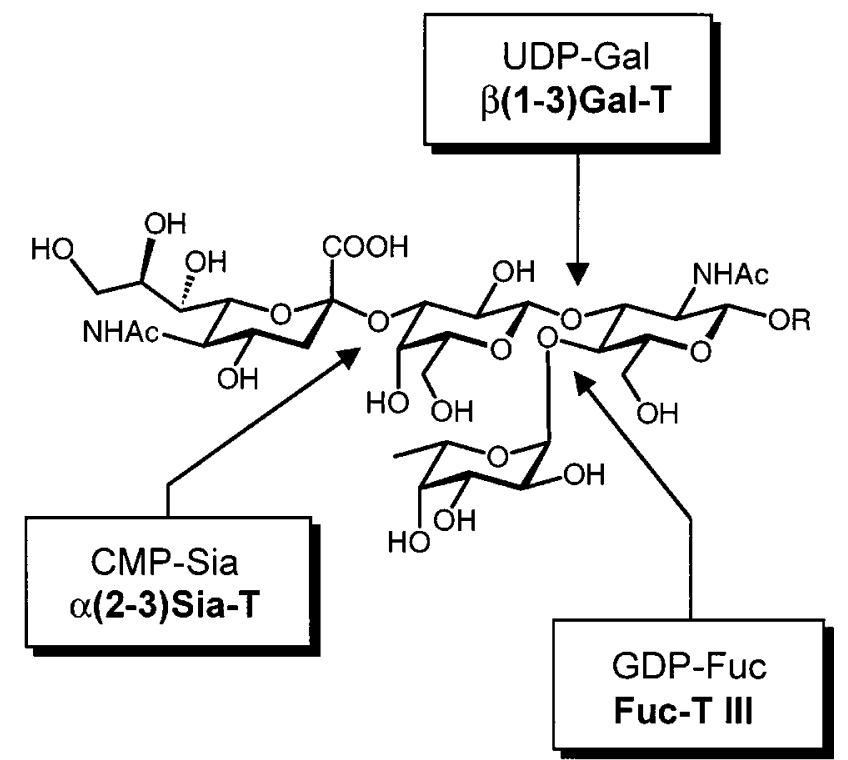

sialyl Lewis ${ }^{\mathrm{a}}(\mathbf{2})$

Figure 1. Glycosyl transferases and sugar nucleotides involved in the enzymatic synthesis of sialyl Lewis ${ }^{\mathrm{x}}$ and sialyl Lewis $^{\mathrm{a}}$

and stereospecifically to a growing oligosaccharide chain. Although nature has developed an almost unlimited number of donor sugars, mammalian cells form their vast variety of cell surface carbohydrates with only eight donor substrates $[15,16]$. In this review we will focus on the chemo-enzymatic synthesis of sialyl Lewis ${ }^{x}$, sialyl Lewis ${ }^{a}$ and derivatives thereof. The glycosyl transferases and the sugar nucleotides involved are summarized in Figures 1 and $2 \mathrm{a}-\mathrm{c}$.

A growing number of publications dealing with the synthesis of non-natural sugar nucleotides have recently appeared. The chemical and/or enzymatic synthesis of these activated donors and various derivatives thereof have been reviewed [16]. Not all of these donors, however, have been probed on the respective transferases. Specificities of transferases towards structural modifications of sugar nucleotides $[13,35]$ are summarized below:

$\beta(1-4)$ Galactosyl transferase tolerates small non-polar replacements of the 2- and 6-OH-group in UDP-galactose [20,23]. $\alpha(2-3)$ Sialyl transferase, either isolated from rat liver or cloned and overexpressed by $\mathrm{CHO}$ cells, transfers sialic acid derivatives, in which the natural 5-N-acetyl group is replaced by non-natural acyl variants including polar and lipophilic residues [25,26]. The 9-OH-group of the sialic acid does not interact with the enzyme and can, therefore, be derivatized by polar and/or bulky aromatic residues. This observation was applied to specifically label oligosaccharides via sialylation [27]. Finally, $\alpha(1-3 / 4)$ fucosyl trans- ferase tolerates quite bulky attachments on the 6-position of fucose $[33,34]$. When the 2- and the 3-OH-group in GDP-fucose are replaced by small substituents [29,30,31], the corresponding sugar nucleotides still act as donors for $\alpha(1-3 / 4)$ fucosyl transferase.

\section{Enzymatic synthesis of sialyl Lewisx $\left(\right.$ sLe $\left.^{x}\right)$ derivatives}

3.1. Galactosylation of non-natural substrates with $\beta(1-4)$ galactosyl transferase

The most intensively studied transferase with respect to donor- and acceptor specificity is $\beta(1-4)$ galactosyl transferase (GalT E.C.2.4.1.22/38) [13,36]. This enzyme transfers $D$-galactose from UDP-galactose $\beta$-selectively onto the 4 position of terminal $\mathrm{N}$-acetylglucosamine to produce $\mathrm{N}$ acetyllactosamine (see Scheme 1). In the presence of $\alpha$-lactalbumine the specificity is altered and $D$-glucose can be used as the acceptor [13,22]

In a structure-activity study aimed at identifing the pharmacophores of $\mathrm{sLe}^{\times}$, we applied standard galactosylation conditions [37] to a series of $\mathrm{N}$-acylglucosamine derivatives with various substitutions on the reducing end [38]. The selected examples (see Table 1) show that lipophilic aglycons (e.g., entry 2,4) as well as protected peptide moieties (entries 6,7) or alkaloids (entry 5) are tolerated. The only limitation to enzymatic galactosylation is the solubility of the acceptor in the incubation buffer [38]. An attractive 
<smiles>O=c1ccn(C2OC(COP(=O)(O)OP(=O)(O[Na])OC3OC(CO)C(O)C(O)C3O)[C@H](O)C2O)c(=O)[nH]1</smiles>

UDP-Gal
Synthesis of:

UDP-Gal

$2-\mathrm{OH}=\mathrm{NHAC}$

$2-\mathrm{OH}=\mathrm{H}$

$2-\mathrm{OH}=\mathrm{OMe}$

$3-\mathrm{OH}$ or $4-\mathrm{OH}=\mathrm{H}$ [21]

$5-\mathrm{O}=\mathrm{S}$

$6-\mathrm{OH}=\mathrm{F}$ or $\mathrm{H}$

$6-\mathrm{OH}=\mathrm{OMe}$

Figure 2a. Selected protocols for the synthesis of UDP-Gal and non-natural derivatives

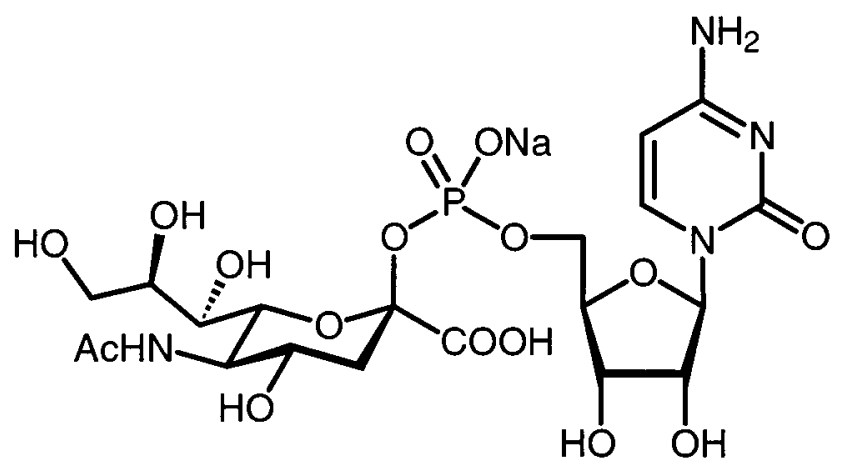

CMP-Sia

Synthesis of:

CMP-Sia

$5-\mathrm{NHAC}=\stackrel{\mathrm{O}}{\mathrm{H}}, \stackrel{\mathrm{l}}{\mathrm{CH}_{3}}, \stackrel{\mathrm{l}}{\mathrm{N}_{\mathrm{NH}_{2}}}$

$5-\mathrm{NHAC}=\underbrace{\mathrm{OH}}_{\mathrm{O}}, \overbrace{}^{\mathrm{NHBz}}$

$9-\mathrm{OH}=\mathrm{N}_{3}, \mathrm{NH}_{3}{ }^{+}, \mathrm{NHAC},>_{\mathrm{H}} \stackrel{\mathrm{N}}{\text { alkyi }}$

9-OH = fluorescin

$9-\mathrm{OH}=\mathrm{SHgMe}$

Figure $\mathbf{2 b}$. Selected protocols for the synthesis of CMP-Sia and non-natural derivatives

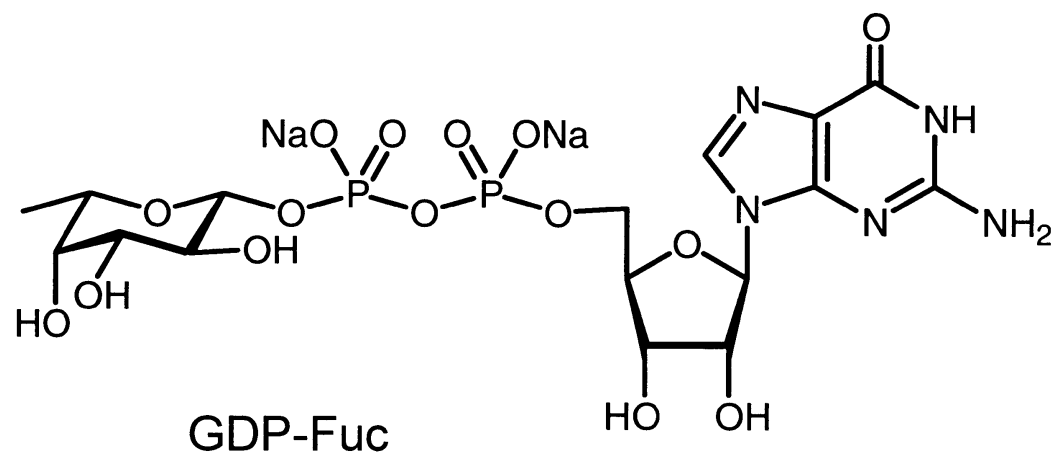

Synthesis of:

GDP-Fuc

$2-\mathrm{OH}=\mathrm{F}, \mathrm{NH}_{2}$

$3-\mathrm{OH}=\mathrm{H}$

$5-\mathrm{CH}_{3}=\mathrm{H}$

$6-\mathrm{H}=\mathrm{OH}$

$6-\mathrm{H}=$ alkyl

$6-\mathrm{H}=$ fluorescent label [33]

6- $\mathrm{H}=$ spacer + sugar

$3-\mathrm{OH}=\mathrm{H} \& 6-\mathrm{H}=\mathrm{OH}$

Figure 2c. Selected protocols for the synthesis of GMP-Fuc and non-natural derivatives 

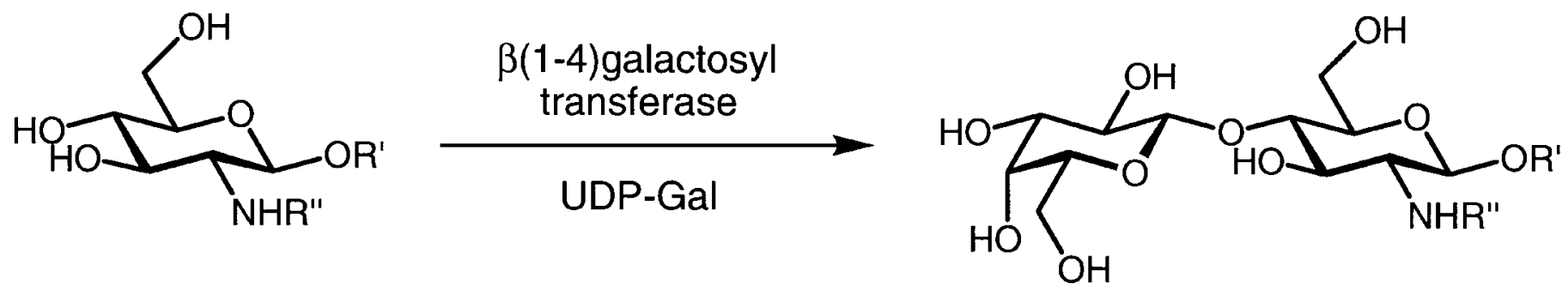

Scheme 1. Transfer of galactose to glucosamine derivatives by $\beta(1-4)$ galactosyl transfer $\left(\mathrm{R}^{\prime}=\left(\mathrm{CH}_{2}\right)_{8} \mathrm{COOMe}\right)$

application of this enzymatic glycosylation technique is the efficient galactosylation of di- and/or oligovalent acceptor compounds [39,40].

$\beta(1-4)$ Galactosyl transferase shows also an unexpectedly broad tolerance towards non-natural $\mathrm{N}$-acyl residues of the acceptor substrate $[36,41,46]$. Preparatively useful yields have been obtained with bulky (entries 10,13,14) or charged substituents (entries 11,12). Moreover, the acyl group can for example be replaced by a sulfonamide (entry 9). These results indicate a high flexibility of $\beta(1-4)$ galactosyl transferase towards their substrates. Whereas this property is useful for large scale preparation, it impedes the rational design of $\beta((1-4)$ galactosyl transferase inhibitors [47,48].

\subsection{Sialylation of non-natural substrates with $\alpha(2-3)$ sialyl transferase}

Chemical sialylations suffer from poor stereoselectivity and low overall yields. This is due to the low reactivity of the tertiary anomeric carbon and the lack of neighboring group assistance [49]. With $\alpha(2-3)$ sialyl transferase (E.C.2.4.99.6), however, sialic acid is transferred from CMP-sialic acid $\alpha$-selectively onto the $3-\mathrm{OH}$ group of a terminal galactose (see Scheme 2).

All of the hydroxyl groups of the galactose unit are essential for substrate recognition by the sialyl transferase [13]. The enzyme does, however, accept a wide variety of acyl groups on the lactosamine nitrogen [36]. The replacement by aromatic or heteroaromatic moieties (entries 3,7 ),

Table 1. Glucosamine derivatives tolerated as substrates by $\beta(1-4)$ galactosyl transferase

\begin{tabular}{|c|c|c|c|c|c|c|c|}
\hline entry & $\mathbf{R}^{\prime}$ (aglycon) & $R^{\prime \prime ~(a c y l ~ g r o u p) ~}$ & yield & entry & $R^{\prime}$ (aglycon) & R“ (acyl group) & yield \\
\hline 1 & $-H$ & $-\mathrm{C}(=\mathrm{O}) \mathrm{OCH}_{2} \mathrm{CH}=\mathrm{CH}_{2}$ & $96 \%$ [38] & 8 & - $\left(\mathrm{CH}_{2}\right)_{8} \mathrm{COOMe}$ & $-\mathrm{C}(=\mathrm{O}) \mathrm{CH}_{3}$ & $95 \%[41]$ \\
\hline 2 & - $\left(\mathrm{CH}_{2}\right)_{8} \mathrm{COOMe}$ & $-\mathrm{C}(=\mathrm{O}) \mathrm{OCH}_{2} \mathrm{CH}=\mathrm{CH}_{2}$ & $95 \%$ [41] & 9 & $-\left(\mathrm{CH}_{2}\right)_{8} \mathrm{COOMe}$ & & $87 \%[41]$ \\
\hline 3 & $-\mathrm{CH}_{2} \mathrm{CH}=\mathrm{CH}_{2}$ & $-\mathrm{C}(=\mathrm{O}) \mathrm{OCH}_{2} \mathrm{CH}=\mathrm{CH}_{2}$ & $93 \%[38]$ & 10 & $-\left(\mathrm{CH}_{2}\right)_{8} \mathrm{COOMe}$ & & $81 \%[41]$ \\
\hline 4 & & $-\mathrm{C}(=\mathrm{O}) \mathrm{OCH}_{2} \mathrm{CH}=\mathrm{CH}_{2}$ & $39 \%[38]$ & 11 & $-\left(\mathrm{CH}_{2}\right)_{8} \mathrm{COOMe}$ & $-\mathrm{C}(=\mathrm{O}) \mathrm{CH}_{2} \mathrm{NH}_{2}$ & $75 \%[41]$ \\
\hline 5 & & $-\mathrm{C}(=\mathrm{O}) \mathrm{CH}_{3}$ & $65 \%[42]$ & 12 & $-\left(\mathrm{CH}_{2}\right)_{8} \mathrm{COOMe}$ & $-\mathrm{C}(=\mathrm{O}) \mathrm{CH}_{2} \mathrm{SO}_{3} \mathrm{Na}$ & $77 \%[41]$ \\
\hline 6 & & $-\mathrm{C}(=\mathrm{O}) \mathrm{CH}_{3}$ & $59 \%[43]$ & 13 & - $\left(\mathrm{CH}_{2}\right)_{8} \mathrm{COOMe}$ & & $74 \%[45]$ \\
\hline 7 & & $-\mathrm{C}(=\mathrm{O}) \mathrm{CH}_{3}$ & $35 \%[44]$ & 14 & $-\left(\mathrm{CH}_{2}\right)_{8} \mathrm{COOMe}$ & & $53 \%[46]$ \\
\hline
\end{tabular}



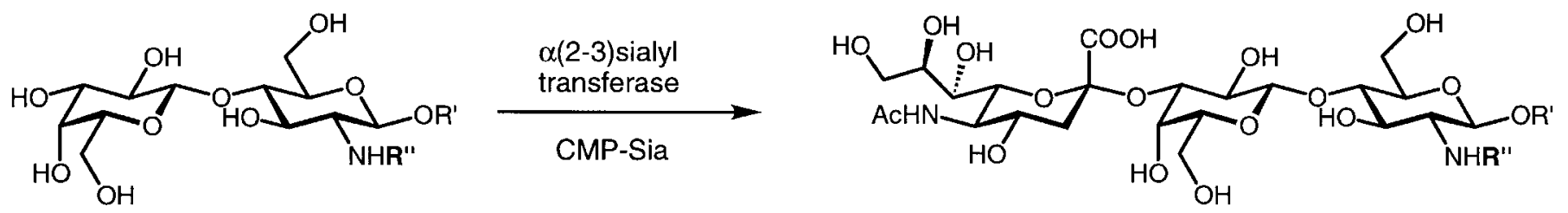

Scheme 2. Enzymatic sialylation of type II disaccharides $\left(\mathrm{R}=\left(\mathrm{CH}_{2}\right)_{8} \mathrm{COOMe}\right)$

charged residues (entries 4,5 ) or sulfonamides (entry 6) [50] is well tolerated. Bulky polar monosaccharides (entry 8) are also easily sialylated in the expected manner [46]. Thus, libraries of sialylated type II sugars-the immediate precursors of the sialyl-Lewis ${ }^{\mathrm{x}}$-tetrasaccharides-are produced rapidly with good overall yields.

3.3 Fucosylation of non-natural substrates with $\alpha(1-3)$ fucosyl transferase (FucT VI)

For the final fucosylation (Scheme 3) of the sialyl $\alpha(2-3)$ lactosamide derivatives recombinant FucT VI was used [51]. FucT VI transfers fucose (Table 3a) as well as fucose derivatives (Table $3 b$ ) $\alpha$-selectively onto the $3-\mathrm{OH}$ group of a $\mathrm{N}$-acyl glucosamide moiety.

The results using modified substrates are summarized in Table 3a. Surprisingly, the natural $\mathrm{N}$-acetyl group of the glucosamine unit is not a key recognition element for FucT VI, although fucosylation takes place at the hydroxyl group adjacent to the N-acyl position [52]. Small (entry 2) or bulky aromatic residues (entries 3,7 ) are accepted. In addition, charged substituents (entry 5) [52], a bulky polar monosaccharide (entry 8) [46] or even a sulfonamide (entry 6) [52] are tolerated. Moreover (see Table 3b), the concomitant replacement of the natural $\mathrm{N}$-acetyl group and the $L$-fucose donor by non-natural $\mathrm{N}$-acyl moieties and
$D$-arabinose (entries 9a-12a) or $L$-galactose (entries 9b-12b), respectively, is well accepted by FucT VI [53]. Thus, sLe $\mathrm{x}^{\mathrm{x}}$-libraries differing in two positions at the same time can be obtained enzymatically for lead discovery or lead optimization programs.

\section{Enzymatic synthesis of sialyl Lewisa ${ }^{\left(s L e^{a}\right)}$ derivatives}

\subsection{Galactosylation of non-natural substrates with} $\beta(1-3)$ galactosyl transferase

$\mathrm{sLe}^{\mathrm{a}}$ is a structural isomer of sLe ${ }^{\mathrm{x}}$ with interchanged attachment of $D$-galactose and $L$-fucose to the glucosamine. The enzymatic assemblage starts with the transfer of $D$-galactose catalyzed by $\beta(1-3)$ GalT to the 3-position of a terminal $\mathrm{N}$-acetylglucosamine (see Scheme 4) yielding a type I (Lewis ${ }^{c}$ ) disaccharide.

Only one report concerning the substrate specificity of $\beta(1-3)$ galactosyltransferase [54] has so far been published. Interestingly, the natural $\mathrm{N}$-acetylgroup of the glucosamide acceptor (entry 1) can be replaced by small aliphatic acyl residues (entries 2-4,6) or polar and charged amides (entry 5) (see Table 4). Despite the close proximity of those variations to the site of galactosylation acceptable yields of a number of Lec-derivatives are obtained.

Table 2. Type II disaccharides tolerated as substrates by $\alpha(2-3)$ sialyl transferase $\left(\mathrm{R}^{\prime}=\left(\mathrm{CH}_{2}\right)_{8} \mathrm{COOMe}\right)$

\begin{tabular}{|c|c|c|c|c|c|}
\hline entry & $R^{\prime \prime \prime ~(a c y l ~ g r o u p) ~}$ & yield & entry & R“ (acyl group) & yield \\
\hline 1 & & $71 \%[38]$ & 5 & & $92 \%[50]$ \\
\hline 2 & & $72 \%[38]$ & 6 & & $92 \%[50]$ \\
\hline 3 & & $81 \%[50]$ & 7 & & $74 \%[50]$ \\
\hline 4 & & $49 \%[50]$ & 8 & & $95 \%[46]$ \\
\hline
\end{tabular}



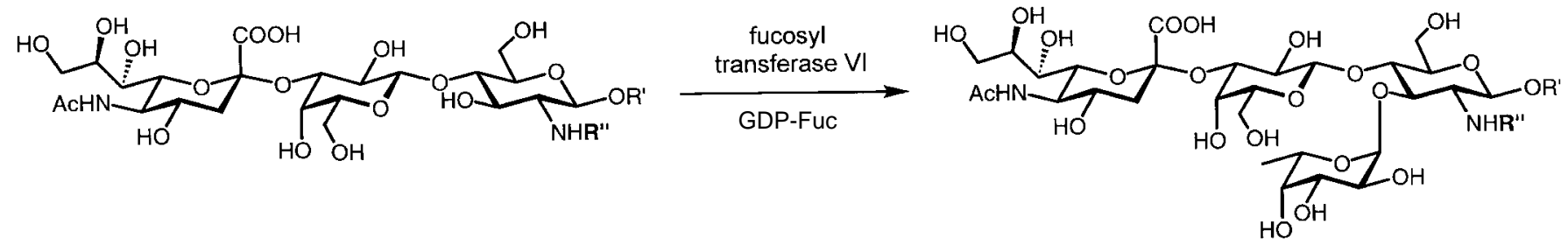

Scheme 3. Enzymatic $\alpha(1-3)$ glycosylation with fucosyl transferase $\mathrm{VI}\left(\mathrm{R}^{\prime}=\left(\mathrm{CH}_{2}\right)_{8} \mathrm{COOMe}\right)$

Table 3a. Fucosylation of non-natural N-acylglucosamides with GDP-fucose

entry

Table 3b. Fucosylation of non-natural N-acylglucosamides with non-natural GDP sugars

\begin{tabular}{|c|c|c|c|}
\hline entry & $R^{\prime \prime}$ (acyl group) & sugar & yield [53] \\
\hline $9 a$ & & $D$-arabinose & $80 \%$ \\
\hline $9 b$ & & L-galactose & $58 \%$ \\
\hline $10 a$ & & $D$-arabinose & $66 \%$ \\
\hline $10 \mathrm{~b}$ & & L-galactose & $66 \%$ \\
\hline $11 a$ & & $D$-arabinose & $54 \%$ \\
\hline $11 b$ & & L-galactose & $82 \%$ \\
\hline $12 a$ & & $D$-arabinose & $62 \%$ \\
\hline $12 b$ & & $L$-galactose & $53 \%$ \\
\hline
\end{tabular}

4.2. Sialylation of non-natural substrates with $\alpha(2-3)$ sialyl transferase

The type II and type I disaccharides are likewise substrates for the rat liver $\alpha(2-3)$ sialyltransferase [13]. Both disaccharides are $\alpha$-selectively sialylated at the 3-position of the terminal galactose (see Scheme 5).

As observed for the type II chain (see section 3.2), $\alpha(2-3)$ SiaT does not interact $\mathrm{N}$-acyl groups in the type I chain (Table 5). The natural $\mathrm{N}$-acetyl group can for example be replaced by aromatic or heteroaromatic (entries 5, 6) or charged amide residues (entries 3,4) [55]. Even sulfonamides (entry 7) and bulky saccharides (entry 8 ) do not impede the proper sialylation [46].

\subsection{Fucosylation of non-natural substrates with} $\alpha(1-4)$ fucosyl transferase (FucT III)

A final incubation of $\mathrm{sLe}^{\mathrm{c}}$ with fucosyl transferase III yields the target sLe ${ }^{a}$. FucT III transfers $L$-fucose $\alpha$-selectively from GDP-fucose onto the 4-position of the N-acetylglucosamine residue (see Scheme 6). 

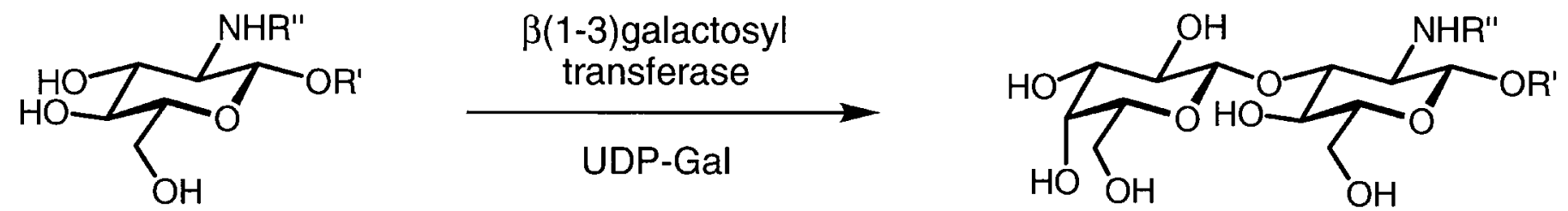

Scheme 4. Transfer of galactose to glucosamine derivatives by $\beta(1-3)$ galactosyl transferase $\left(R^{\prime}=\left(\mathrm{CH}_{2}\right)_{8} \mathrm{COOMe}\right)$

Table 4. $\beta(1-3)$ Galactosylation of non-natural glucosamides $\left(\mathrm{R}^{\prime}=\left(\mathrm{CH}_{2}\right)_{8} \mathrm{COOMe}\right)$

\begin{tabular}{|c|c|c|c|c|c|}
\hline entry & $R^{\prime \prime}$ (acyl group) & yield [54] & entry & $R^{\prime \prime}$ (acyl group) & yield [54] \\
\hline 1 & & $97 \%$ & 4 & & $30 \%$ \\
\hline 2 & & $34 \%$ & 5 & & $51 \%$ \\
\hline 3 & & $61 \%$ & 6 & & $59 \%$ \\
\hline
\end{tabular}
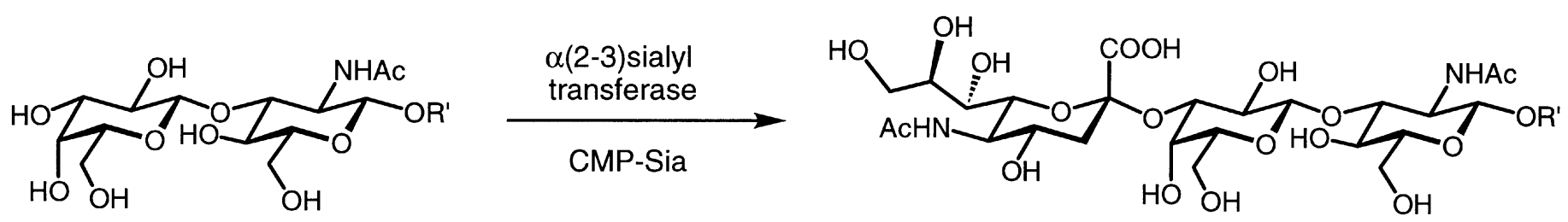

Scheme 5. Enzymatic sialidation of type I disaccharides $\left(\mathrm{R}^{\prime}=\left(\mathrm{CH}_{2}\right)_{8} \mathrm{COOMe}\right)$

Table 5. Type I disaccharides tolerated by $\alpha(2-3)$ sialyl transferase $\left(\mathrm{R}^{\prime}=\left(\mathrm{CH}_{2}\right)_{8} \mathrm{COOMe}\right)$

\begin{tabular}{|c|c|c|c|c|c|}
\hline entry & $R^{\prime \prime}$ (acyl group) & yield & entry & $\mathbf{R}^{\prime \prime}$ (acyl group) & yield \\
\hline 1 & & $75 \%[55]$ & 5 & & $72 \%[55]$ \\
\hline 2 & & $71 \%[55]$ & 6 & & $73 \%[55]$ \\
\hline 3 & & $59 \%[55]$ & 7 & & $94 \%[55]$ \\
\hline 4 & & $53 \%[55]$ & 8 & & $70 \%[46]$ \\
\hline
\end{tabular}




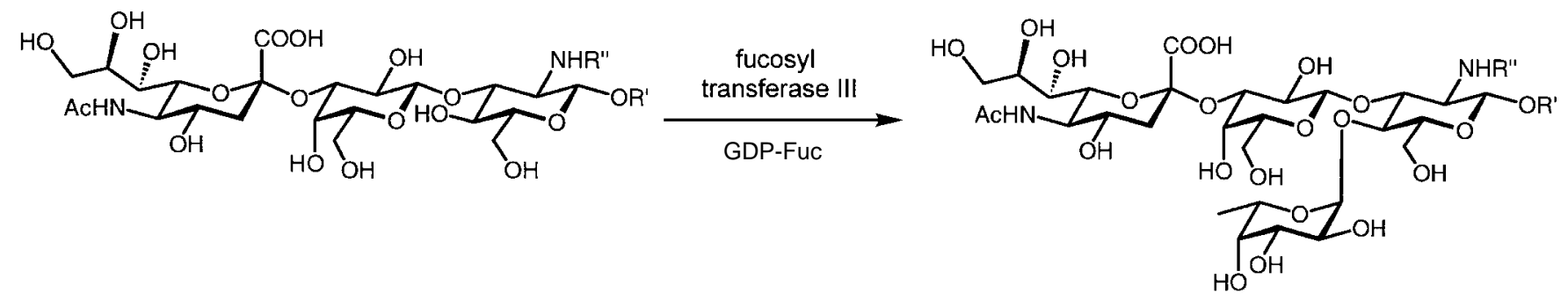

Scheme 6. Enzymatic $\alpha(1-3)$ glycosylation with fucosyl transferase III $\left(\mathrm{R}^{\prime}=\left(\mathrm{CH}_{2}\right)_{8} \mathrm{COOMe}\right)$

Table 6. Fucosylation of non-natural N-acylglucosamides with GDP-fucose and non-natural GDP-sugars.

\begin{tabular}{|c|c|c|c|}
\hline entry & R“" (acyl group) & sugar & yield [55] \\
\hline 1 & & L-fucose & $97 \%$ \\
\hline 2 & & L-2-deoxy-2-fluoro-fucose & $73 \%$ \\
\hline 3 & & $\begin{array}{l}L \text {-fucose } \\
D \text {-arabinose } \\
L \text {-galactose }\end{array}$ & $\begin{array}{l}78 \% \\
82 \% \\
77 \%\end{array}$ \\
\hline 4 & & L-galactose & $81 \%$ \\
\hline 5 & & L-fucose & $99 \%$ \\
\hline 6 & & $L-2-$ deoxy-2-amino-fucose & $32 \%$ \\
\hline 7 & & $\begin{array}{l}L \text {-fucose } \\
D \text {-arabinose }\end{array}$ & $\begin{array}{l}80 \% \\
84 \%\end{array}$ \\
\hline 8 & $-\mathrm{OCH}_{3}$ & $L$-fucose & $82 \%$ \\
\hline
\end{tabular}


Recent investigations revealed key polar groups on the sugar nucleotide and the acceptor substrates recognized by the enzyme $[13,56]$. Since the N-acetyl residue of the glucosamine moiety is not essential for recognition by the transferase, it is open for wide modifications.

Selected examples are presented in Table 6 [55]. Small neutral (entries 1-3) or charged (entry 4) amide residues are well tolerated. Bulky aromatic residues are accepted even in combination with non-natural fucose donors (entries 5-7). Tetrasaccharide (entry 8) is also fucosylated in high yield. Thus the transfer of non-natural donors onto non-natural acceptors opens an elegant access to sLea-libraries with altered on fucose and glucosamine moieties.

\section{Outlook}

In the reviewed examples, the glycosyl transferases were found to have a remarkable flexibility in the recognition of both the sugar nucleotide donors and the acceptor substrates. In many cases the reaction rates are very low compared to the natural reaction. Such rates, however, proved to be sufficient for the synthesis of preparative amounts of oligosaccharide derivatives.

In cases where modifications on both the sugar nucleotide and the acceptor substrate are tolerated by the glycosyl transferases, the enzymatic synthesis offers an efficient approach to thematic or random oligosaccharide libraries.

A severe drawback for the feasibility of the enzymatic synthesis of oligosaccharides and derivatives thereof stems from the availability of glycosyl transferases and sugar nucleotides. Although an increasing number of transferases are commercially available, they are still prohibitively expensive, particularly for synthesis on a preparative scale. For this reason, a growing number of industrial and academic laboratories have initiated programs to clone and overexpress their own transferases for mechanistic and synthetic studies.

Since the commercially available sugar nucleotides are also prohibitively expensive, numerous chemical and chemo-enzymatic approaches for their syntheses have been developed in recent years. They have decisively improved the availability of activated sugars in preparative amounts and therefore the feasibility of the enzymatic synthesis of oligosaccharides and derivatives thereof.

\section{References}

1 Varki A (1993) Glycobiology 3: 97-130; Witczak ZJ (1995) Curr Med Chem 1: 392-405; Simon PM (1994) Exp Opin Invest Drugs 3: 223-39; McAuliffe JC, Hindsgaul O (1997) Chemistry \& Industry, 170-74.

2 Karlsson K-A (1995) Curr Opin Struct Biol 5: 622-35; Zopf D (1996) Lancet 347: 1017-21.

3 Hakomori S-J (1989) Adv Cancer Res 52: 257-331; Dennis JW (1988) Cancer Surveys 7: 753-94.
4 Welply JK, Keene JL, Schmuke JJ, Howard SC (1994) Biochem Biophys Acta 1197: 215-26.

5 Stein KE (1994) Int J Technol Assessment in Health Care 10: 167-76.

6 Sharar SR, Winn RK, Harlan JM (1995) Springer Semin Immunopathol 16: 359-78.

7 Granger DN, Schmid-Schönbein GW, eds. (1995) Physiology and Pathophysiology of Leukocyte Adhesion New York: Oxford University Press.

8 Phillips ML, Nudelman E, Gaeta FCA, Perez M, Singhal AK, Hakomori S, Paulson JC (1990) Science 250: 1130-32; Walz G, Aruffo A, Kolanus W, Bevilacqua MP, Seed B (1990) Science 250: 1132-35; Bevilacqua MP (1993) Annu Rev Immunol 11: 767-804; McEver RP (1994) Curr Opin Immunol 6: 75-84; Rosen SD, Bertozzi CR (1994) Curr Opin Cell Biol 6: 663-73; Springer TA (1994) Cell 76: 301-14.

9 Koenig A, Jain R, Vig R, Norgard-Sumnicht KE, Matta KL, Varki A (1997) Glycobiology 7: 79-93.

10 Magnani JL (1991) Glycobiology 1, 318-20; Berg EL, Robinson MK, Mansson O, Butcher EC, Magnani JL (1991) J Biol Chem 266: 14869-72; Berg EL, Magnani JL, Warnock RA, Robinson MK, Butcher EC (1992) Biochem Biophys Res Commun 184: 1048-55.

11 Scheffler K, Ernst B, Katopodis A, Magnani JL, Wang W-T, Weisemann R, Peters T (1995) Angew Chem Int Ed Engl 34: 1841-44; Scheffler K, Brisson J-R, Weisemann R, Magnani JL, Ernst B, Peters T (1997) J Biomol NMR 9: 423-36; Henrichsen D, Ernst B, Magnani JL, Wang W-T, Meyer B, Peters T (1999) Angew Chem Int Ed. Engl 38: 98-102; Harris R, Kiddle GR, Field RA, Ernst B, Magnani JL, Homans S (1999) J Am Chem Soc 14: 2546-51; Jahnke W, Kolb HC, Blommers MJJ, Magnani JL, Ernst B (1997) Angew Chem Int Ed Engl 36: 2603-7; Kolb HC, Ernst B (1997) Pure Appl Chem 69: 1879-84; Kolb HC, Ernst B (1997) Chem Eur J 3: 1571-78; Hanessian S, Reddy GV, Huynh HK, Pan J, Pedatella S, Kolb HC, Ernst B (1997) Bioorg Med Chem Lett 7: 2729-34; Bänteli R, Ernst B (1997) Tetrahedron Lett 38: 4059-62; Roche D, Bänteli R, Winkler T, Casset F, Ernst B (1998) Tetrahedron Lett 38: 2545-48; Hanessian S, Huynh HK, Reddy GV, McNaughton-Smith G, Ernst B, Kolb HC, Magnani JL, Sweeley C (1998) Bioorg Med Chem Lett 8: 2803-6; Tsai C-Y, Park WKC, Weitz-Schmidt G, Ernst B, Wong C-W (1998) Bioorg Med Chem Lett 8: 2333-38; Norman KE, Anderson GP, Kolb HC, Ley K, Ernst B (1998) Blood, 91: 475-83.

12 Toone EJ, Simon ES, Bednarski MD, Whitesides GM (1989) Tetrahedron 45: 5365-422; David S, Augé C, Gautheron C (1991) Adv Carbohydr Chem Biochem 49: 175-89; Drueckhammer DG, Hennen WJ, Pederson RL, Barbas CF, Gautheron CM, Krach T, Wong C-H (1991) Synthesis 7: 499-525; Ichikawa Y, Look GC, Wong C-H (1992) Anal Biochem 202: 215-21;

13 Hindsgaul O, Palcic MM (1996) Trends Glycosci Glycotechnol 8: 37-49.

14 Leloir LF (1971) Science 172: 1299-303.

15 Heidlas JE, Williams KW, Whitesides GM (1992) Acc Chem Res 25: 307-14.

16 Öhrlein R In Ernst B, Hart G, Sinay P, eds Chemistry and Biology of Carbohydrates: A Comprehensive Handbook. New York: Wiley-VCH (in preparation).

17 Heidlas JE, Lees WJ, Whitesides GM (1992) J Org Chem 57: $152-57$. 
18 YAMASA-Corporation 1-23-8, Nihonbashi-Kagigaracho, Chouku, Tokyo 103, JPN.

19 Srivastava G, Hindsgaul O, Palcic MM (1993) Carbohydr Res 245: $137-44$.

20 Endo T, Kajihara Y, Kodama H, Hashimoto H (1996) Bioorg Med Chem 4: 1939-48.

21 Uchiyama T, Hindsgaul O (1998) J Carbohydr Res 17: 1181-90.

22 Yuasa H, Hindsgaul O, Palcic MM (1992) J Am Chem Soc 114: 5891-92.

23 Kajihara Y, Endo T, Ogasawara H, Kodama H, Hashimoto H, (1995) Carbohydr Res 269: 273-94.

24 Jülich Enzyme Products, Germany, offers bulk quantities of CMP-sialic acid on request.

25 Brossmer R, Gross HJ (1994) Methods Enzymol 247: 153-76.

26 Chappell MD, Halcomb RL (1997) Tetrahedron 53: 11109-120.

27 Brossmer R, Gross HJ (1988) Eur J Biochem 177: 583-89.

28 Martin R, Witte KL, Wong C-H (1998) Bioorg Med Chem 6: 1283-89.

29 Baisch G, Öhrlein R (1997) Bioorg Med Chem 5: 383-91.

30 Gokhale UB, Hindsgaul O, Palcic MM (1990) Can J Chem 68: 1063-71.

31 Binch H, Stangier K, Thiem J (1998) Carbohydr Res 306: 409-19.

32 Vogel C, Bergemann C, Ott A-J, Lindhorst TK, Thiem J, Dahlhoff WV, Hällgren C, Palcic MM, Hindsgaul O (1997) Liebigs Ann 601-12.

33 Hällgren C, Hindsgaul O (1995) J Carbohydr Res 14: 453-64.

34 Srivastava G, Kaur KJ, Hindgaul O, Palcic MM (1992) J Biol Chem 267: 22356-61.

35 Crawley SC, Palcic MM (1996) In Khan SH, O’Neill RA, eds Modern Methods in Carbohydrate Synthesis. Amsterdam: Harwood Academic Publishers, pp 492-517.

36 Öhrlein R (1999) Topics in Curr Chem 200: 227-54.

37 Palcic MM (1994) Methods Enzymol 230: 300-16.

38 Öhrlein R, Ernst B, Berger EG (1992) Carbohydr Res 236: 335-38.
39 Ats S-C, Lehmann J, Petry S (1994) Carbohydr Res 252: 325-32.

40 Baisch G, Öhrlein R (1996) Angew Chem Int Ed Engl 35: 1812-15.

41 Baisch G, Öhrlein R, Ernst B (1996) Bioorg Med Chem Lett 6: 749-54.

42 Kren V, Augé C, Sedmera P, Havlìcek V, (1994) J Chem Soc Perkin I, 2481-84.

43 Schultz M, Kunz H (1993) Tetrahedron Assym 4: 1205-20.

44 Wong C-H, Schuster M, Wang P, Sears P (1993) J Am Chem Soc 115: 5893-901.

45 Öhrlein R (1997) Biotrans 97, abstract C10, La Granded Motte, France.

46 Baisch G, Öhrlein R (1998) Bioorg Med Chem 6: 1673-82.

47 Schmidt RR, Frische K (1993) Bioorg Med Chem Lett 3:1747-50.

48 Hayashi T, Murray BW, Wang R, Wong C-H (1997) Bioorg Med Chem 5: 497-500.

49 Shaheer HK, Hindsgaul O (1994) In Fukuda M, Hindsgaul O, eds Molecular Glycobiology. Oxford: IRL-Press, pp 206-29.

50 Baisch G, Öhrlein R, Streiff M, Kolbinger F (1998) Bioorg Med Chem Lett 8: 755-58.

51 Koszdin KL, Bowen BR (1992) Biochem Biophys Res Commun 187: 152-57; Ge Z, Chan NWC, Palcic MM, Taylor DE (1997) $J$ Biol Chem 272: 21357-63.

52 Baisch G, Öhrlein R, Katopodis A, Ernst B (1996) Bioorg Med Chem Lett 6: 759-62.

53 Baisch G, Öhrlein R, Katopodis A, (1997) Bioorg Med Chem Lett 7: 2431-34.

54 Baisch G, Öhrlein R, Streiff M, Kolbinger F (1998) Bioorg Med Chem Lett 8: 751-54.

55 Baisch G, Öhrlein R (1998) Carbohydr Res 312: 61-72.

56 Du M, Hindsgaul O (1996) Carbohydr Res 286: 87-105.

Accepted 12 April 1999. 